\title{
1. Judicial dialogue in European private law: introductory remarks
}

Fabrizio Cafaggi and Stephanie Law

\section{OVERVIEW OF THE TEXT}

This text contributes to the ongoing debates surrounding the development of European private law (EPL), paying particular attention to European consumer law. It is oft said that EPL in general, and especially as it relates to consumer protection, is in a constant state of flux. It is currently undergoing substantive, procedural and institutional transformations, which shape its scope, content and formation, interpretation, application and enforcement of its norms, as well as the tools and mechanisms for its development. This book examines the impact of judicial dialogue on EPL development and the regulation of private law relationships. ${ }^{1}$ To this end, it offers novel insights from a range of perspectives related to the role(s) played by the national courts, the Court of Justice of the European Union (CJEU), and the European Court of Human Rights (ECtHR). The book aims to facilitate the better understanding of how EPL develops and how its direction is shaped not only by judicial dialogue, to the extent that it exists, but also by a shift to institutional dialogue. The evolution of EPL is shaped by a number of transformations, including adjustments to the allocation of tasks between the European and national courts, the erosion of procedural autonomy (largely resulting from CJEU case law and from the increasing involvement of the EU legislature in matters of enforcement) ${ }^{2}$

1 On the impact of EU law on private law relationships, see Dorota Leczykiewicz and Stephen Weatherill (eds), The Involvement of EU Law in Private Law Relationships (Hart 2013) and Arthur S. Hartkamp, European Law and National Private Law (Intersentia 2nd edn. 2016), and on EU more generally, see Juan. A Mayoral and Marlene Wind, 'Introduction: National Courts Vis- $\dot{A}-V i s$ EU Law. New Issues, Theories and Methods' in Bruno de Witte et al (eds), National Courts and EU Law: New Issues, Theories and Methods (Edward Elgar Publishing 2016)

2 Transformations are taking place both at the substantive and procedural level; in the latter context, the role of judges - and in particular, their ex officio 
and the growing role of European and national regulators in the actual enforcement of European private and consumer law. ${ }^{3}$ By analysing these dimensions of change, the book also aims to identify future avenues of research and facilitate the further advancement of the field.

These transformative developments generate fundamental questions concerning the shape, scope and character of EPL, the mechanisms engaged in the making of EPL and the tools used to advance its evolution. Drawing insights on the foundational endeavours of the EU legislature, and the role of the national courts and the CJEU in interpreting, applying and enforcing EU law (often provoking legislative change in the Member States), the book explores the shifting power relationship between legislation, adjudication and regulatory enforcement and examines the influence of this development on the Europeanization of private law.

Each chapter initially examines the development of EPL from the perspective of the relationships that exist between the courts and that evolve via judicial cooperation; they also identify the basis and character of such cooperation. Others go further and encompass an analysis of the scope for this cooperation to extend beyond the judiciary, that is, to engage the European and national legislatures, administrative and alternative regulators and dispute resolution facilitators that are typically responsible for law making, interpretation and enforcement. To this end, the contributions also aim to identify the relative influence of each mechanism of law making and enforcement. ${ }^{4}$ Judicial dialogue, while highly relevant, is of course only part of the picture. Indeed, the analysis undertaken suggests that not only judges but also regulators are engaged in dialogue and that cooperation between them often concerns matters relating to enforcement. The book therefore identifies the existence of a shift from judicial to institutional dialogue and highlights the need for its better understanding, in order to incorporate all actors - beyond courts to encompass also regulatory bodies relevant for its application and enforcement into the multilevel structure of EPL.

The contributions also examine the impact of these mechanisms of

powers, their ability to request the reformulation of legal arguments and to seek evidence, to define and allocate the burden of proof, and to design effective, dissuasive and proportionate remedies - is key.

3 See Bruno de Witte and Hans-Wolfgang Micklitz (eds), The European Court of Justice and the Autonomy of the Member States (Intersentia 2011).

4 See, for previous comprehensive analyses, Roger Brownsword, HansWolfgang Micklitz, Leone Niglia and Stephen Weatherill (eds), The Foundations of European Private Law (Hart 2011) and Leczykiewickz and Weatherill, n. 1. 
development, and particularly of judicial dialogue at the national level ${ }^{5}$ and across different fields of EPL depending inter alia on the character of the system of private law in the relevant Member States, the mechanisms for the implementation and transposition of Union legislation and the character of integration that is subsequently advanced therein. ${ }^{6}$ We can identify key sets of evolutions and transformations from these perspectives; these are analysed in depth via a collection of diverse contributions, which facilitate a transatlantic enquiry (Scirica), examine the rationales underpinning the engagement of national courts with the CJEU (Gómez Pomar and Lyczkowska, Józon) and the methodological approaches behind the preliminary reference procedure (Timmermanns), touch upon the constitutionalization of private law and examine the impact of fundamental rights discourses on private relationships, including the impact of the Charter of Fundamental Rights (CFR) on the boundaries, functions and development of European private law (Safjan and Colombi Ciacchi), and the foundational concepts (Law), and enforcement of consumer law (Cafaggi).

\section{(i) The Making of European Private Law and Judicial Dialogue}

At the outset, it is necessary to set out the rough analytical - normative and institutional - framework to position the research questions examined in the book. This framework consists of two main component parts: the first, the relevant conceptualization of private law, and the second, the conceptualization of cooperation and dialogue. Beginning with the former, it is prudent in the context of a study of private law and of course in light of its Europeanization to acknowledge its character and its place in the field of EU law. For the purposes of the text a broad understanding of private law is adopted; it is understood to encompass those rules that regulate the relationships of private parties in a multilevel system.

As noted above, EPL seems to be in an almost constant state of development; initially rather modestly affected by legislative endeavours and the political processes underpinning European integration, an increasingly large body of secondary EU law affecting private law relationships and private autonomy has ensured that national private laws have been considerably transformed by EU endeavours in recent years. ${ }^{7}$ The EU

That is, across different legal traditions and cultures.

6 Concerning, for example, whether the national system transposes European private law legislation into a civil code, into individual pieces of legislation, some parts into a consumer code and others into another specialized body of law.

7 See Stephen Weatherill, 'The Elusive Character of Private Autonomy in EU Law' in Dorota Leczykiewicz and Stephen Weatherill (eds), The Images of the 
norms that regulate private relationships are predominantly substantive in their nature. Since the 1980s, the EU has legislated in the core of private law for package travel, unfair contract terms, consumer credit and consumer rights, e-commerce, product liability, IP rights, financial markets and investment protection, among other substantive private law interests. However, the EU has also made limited inroads into national civil procedures. ${ }^{8}$ In terms of remedies, the EU has legislated for injunctive relief for consumers, the enforcement of IP rights and ADR and provided recommendations on collective redress, and has of course legislated for cross-border civil procedure, establishing regimes that aim to facilitate mutual trust as well as autonomous European civil procedures. ${ }^{9}$ This is one trend among others that has begun to undermine the principle of national procedural autonomy. ${ }^{10}$ Indeed the correlation between rights and remedies and the principles of effectiveness also makes it impossible to preserve the conventional allocation between the EU (rights) and the Member States (remedies). ${ }^{11}$

The chapters deal 1) with issues arising in the development of substantive and procedural private law via the legislature and CJEU, which

Consumer in EU Law: Legislation, Free Movement and Competition Law (Hart 2016) 29.

8 While the Union has competence to legislate for cross-border civil procedure in Arts 67 and 81 TFEU, traditionally a distinction has been drawn between substantive and procedural private law, and it is difficult to identify a competence basis for any possible future harmonization of national civil procedures. It should be noted that this has not been identified as a definitive step but as one option in the Commission's regulatory REFIT of the consumer acquis. See European Commission, 'Evaluation and Fitness Check Roadmap' (Available at: http:// ec.europa.eu/smart-regulation/roadmaps/docs/2016_just_023_evaluation_consumer_law_en.pdf; Last Accessed: 14.06.2016).

9 Including the Brussels and Rome regimes, the European Order for Payment and the European Small Claims Procedure, amongst others.

10 It is worth noting that the foundations, existence and viability of the principle has been called into question, partly as a result of this line of jurisprudence of the CJEU; see, for example, Michel Bobek, 'Why There Is No Principle of Procedural Autonomy of the Member States' and Adelina Adinolfi, 'The "Procedural Autonomy" of Member States and the Constraints Stemming from the ECJ's Case Law: Is Judicial Activism Still Necessary?', both in de Witte and Micklitz (eds), n. 3, 305 and 281. See also, on the role of the national courts in the implementation of EU law, Bruno de Witte et al (eds), National Courts and EU Law: New Issues, Theories and Methods (Edward Elgar Publishing 2016).

11 See Walter van Gerven, 'Of Rights, Remedies and Procedures' (2000) 37 CMLR 501. 
directly fall within areas of EU competence ${ }^{12}$ and 2) those that might rather be deemed to cross the boundaries of its field of competence. ${ }^{13}$ The trigger for much of the discussion comes from the greater role that has seemingly been attributed to both the national and European courts and also the significance attached to the mechanisms that underpin these functions, including the preliminary reference procedure. ${ }^{14}$ Recent years have seen an increase in the number of questions referred to the CJEU by the national courts for a preliminary judgment on the interpretation of a rule derived from EU law or a finding on the compatibility of national and EU rules. ${ }^{15}$ The increase in the number of references extends the possible scope for dialogue between the national courts and the CJEU. In Figures 1.1 and 1.2, a steady incline in the number of questions referred and cases completed by the CJEU is identifiable across all subject areas and in relation to consumer protection specifically.

The starting point of analysis is the following: the national courts and the CJEU have long had a role to play in the development of EPL as the rules governing private relationships have typically been enforced in national courts; a private party normally brings a civil action for compensation to redress the harm arising from the breach of those private law rules by another party to that relationship. The nature of enforcement is typically individual, judicial and private. ${ }^{16}$ The significance of judicial

12 That is, the Union's use of Art.114 TFEU for the completion of the internal market.

13 An example of the latter arises in respect of the CJEU's identification and development of procedural requirements by which national courts are bound and which have required amendments be made to national procedural rules. The case law of the CJEU is cited in section iii below.

14 On the role of the preliminary reference as an instrument of judicial dialogue, see Opinion 2/13, EU:C:2014:2454.

15 According to the General Report of the CJEU, and the most recent of 2015, an increase from 302 'new' preliminary references in 2009 to 436 in 2015. (Available at: http://curia.europa.eu/jcms/jcms/P_192323/; Last Accessed: 13.04.2016). Of course, references come from different Member States, and from some more than others; while, as noted Spain, and certain Central and Eastern European Member States are particularly motivated in their engagement of the Art.267 TFEU procedure, the Supreme Court of the United Kingdom (and previously as the House of Lords) has twice considered it unnecessary to refer to the CJEU for an interpretation of the meaning of key terms under the UCTD: Director General of Fair Trading $v$ First National Bank [2001] UKHL 52 and Office of Fair Trading v Abbey National plc and others [2009] UKSC 6.

16 Olha O. Cherednychenko 'Editorial - Public and Private Enforcement of European Private Law: Perspectives and Challenges' (2015) 23 ERPL 481. 


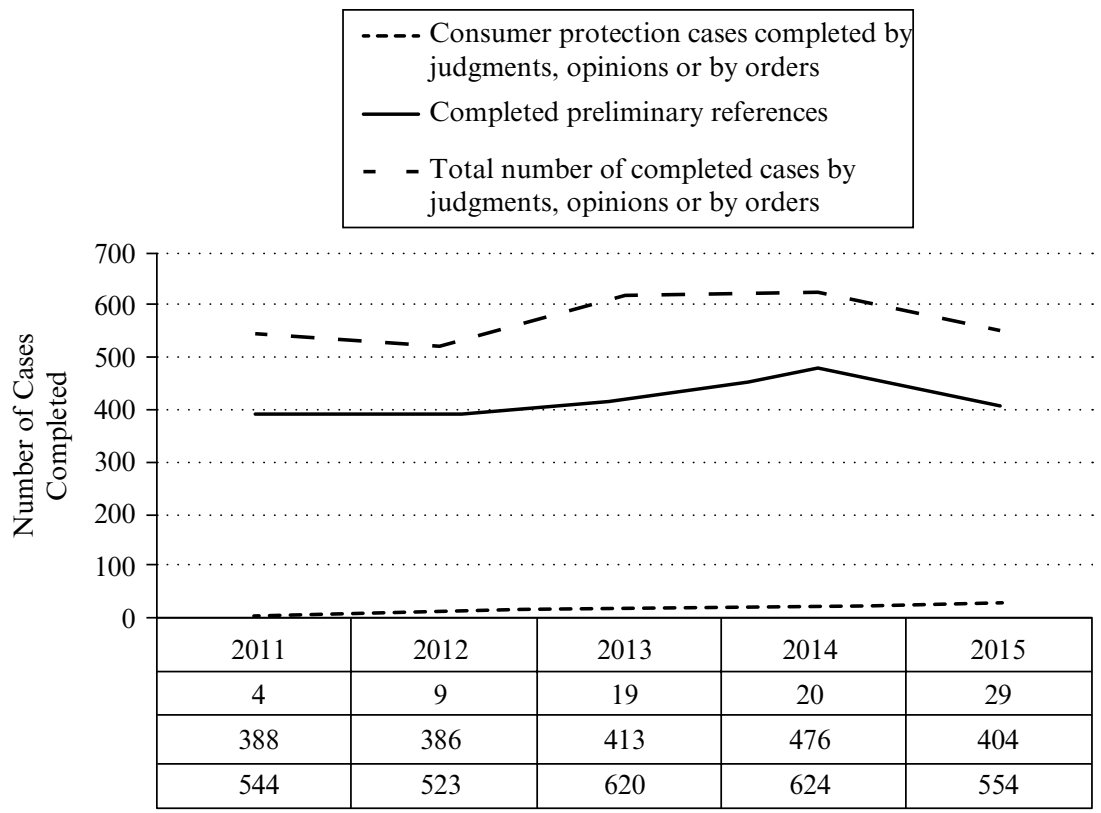

Figure 1.1 Cases completed by judgments, by opinions or by orders, 2011-15

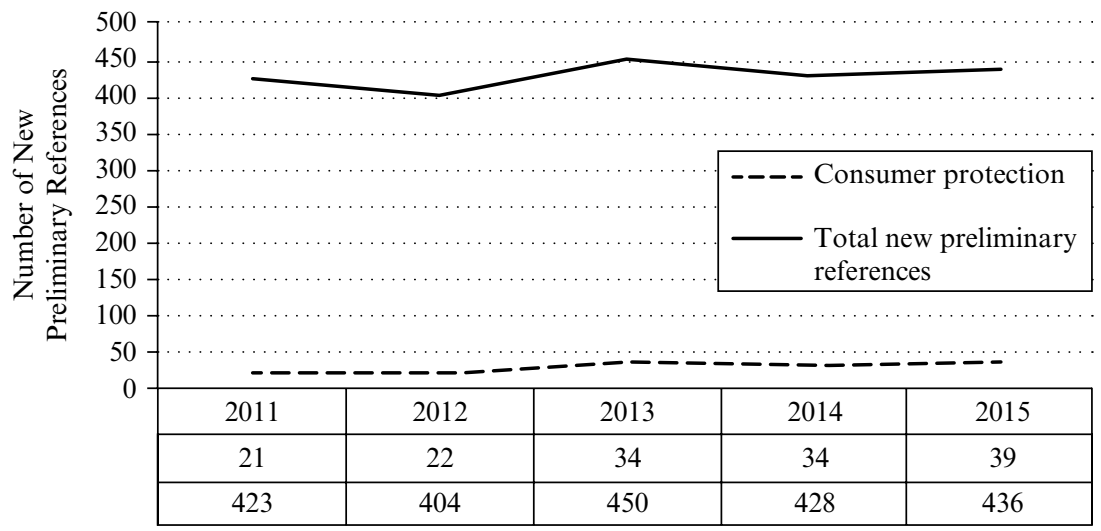

Figure 1.2 Preliminary references, total and concerning consumer protection 
law making has therefore long been underlined. ${ }^{17}$ This book therefore begins from the perspective of the importance of judicial dialogue, including conflicts and cooperation, the function of various judicial techniques as a means to promote dialogue and the role of national courts as agents of European legal integration. ${ }^{18}$

The use of the Art.267 TFEU preliminary reference procedure has triggered vertical dialogue between the national and European courts. The duty to submit a preliminary reference - established in the Lisbon Treaty - has recently been correlated to the existence of conflicts that arise between courts within a single Member State and between Member States. The CJEU promotes horizontal dialogue between national courts by harnessing the preliminary reference procedure as a mechanism that could resolve potential conflicts arising from divergent or conflicting interpretations of EPL norms given by national courts. ${ }^{19}$ As such, it is legitimate for a court, for example, the French Cour de Cassation, to make a preliminary reference if it realizes that it is giving a divergent interpretation of an EU rule from the Hungarian Kuria, the German Bundesgerichtshof or the UK Supreme Court, This innovative use of preliminary references could promote a more intense horizontal dialogue among national courts in light of the guidance provided by the CJEU. The use of the preliminary reference procedure as a mechanism in the enforcement of EPL rules may therefore lead to the judicial governance of divergences in the interpretation of EU legislation. ${ }^{20}$ This process contributes to the further modification of the conventional distinction between rights (EU) and remedies (Member States), illustrating the weaknesses of multilevel architectures that do not account for conflicts and interactions.

Judicial dialogue is stimulated by the application of the principles of

17 Including, for example, the fundamental rights dimension - namely, the constitutionalization of private law - that emerges from the increased focus on adjudication; see Hans-Wolfgang Micklitz (ed.), The Constitutionalization of Private Law (OUP 2014).

18 Anne-Marie Slaughter, Alec Stone Sweet, and Joseph H.H. Weiler (eds), The European Court and the National Courts-Doctrine and Jurisprudence: Legal Change in its Social Context (Hart 1998) and Alec Stone Sweet, The Judicial Construction of Europe (OUP 2004).

19 Case C-160/14 Ferreira da Silva e Brito and Others EU:C:2015:565, in which the Court holds inter alia that where there are conflicting decisions between lower national courts, a court or tribunal against whose decision there is no judicial remedy, is obliged to refer to the CJEU in line with Art.267(3) TFEU.

20 See Fabrizio Cafaggi, 'The Making of European Private Law: Governance Design' in Fabrizio Cafaggi and Horatia Muir Watt (eds), Making European Private Law: Governance Design (Edward Elgar Publishing 2008). 
equivalence and effectiveness in the enforcement of EPL, and particularly of consumer law, within the national courts. ${ }^{21}$ Against this background, judicial dialogue has expanded the application of general principles of EU law to private relationships beyond the specific intermediation of EU legislation; ${ }^{22}$ that is to say, the CJEU has provided for the direct applicability of EU principles, for example of non-discrimination, to private parties. ${ }^{23}$ These developments of rights and remedies in consumer law therefore find parallels in the horizontal application of fundamental rights. ${ }^{24}$ Moreover, and in line with the application of the principles of effective and equivalent protection, judicial dialogue has provided a mechanism for the development of not only the substantive but also the procedural dimensions of consumer law. ${ }^{25}$ In particular, the development of procedural law is increasingly driven by the application of the CFR and Art.47 thereof. While the horizontal application of fundamental rights clearly influence the evolution of EPL, it remains unclear to what extent the CFR itself impacts its boundaries, content and functions. ${ }^{26}$ The CFR - binding as primary law, post-Lisbon Treaty - has been engaged by the CJEU and is generating changes in substantive national consumer law, and in the related rules of civil procedure, for example, in order to ensure, in light of Art.47 CFR, the right to an effective remedy and to a fair trial; this right may be invoked on the one hand in favour of consumers, and on the other, in favour of professionals. ${ }^{27}$ Moreover, the right to be heard

21 See Takis Tridimas, 'The ECJ and the National Courts: Dialogue, Cooperation and Instability' in Anthony Arnull and Damian Chalmers (eds), The Oxford Handbook of European Union Law (OUP 2015) 403, Nina Poltorak, European Union Rights in National Courts (Kluwer 2015) 39 et seq., de Witte and Micklitz, n. 3.

22 See Arthur S. Hartkamp, 'The General Principles of EU Law and Private Law' (2011) 75 Rabels Zeitschrift für ausländisches und internationales Privatrecht 241.

23 See Case C-144/04 Mangold EU:C:2005:709; Case C-555/07 Kücükdeveci EU:C:2010:21 and Case C-441/14 Dansk Industri EU:C:2016:278.

24 See Chantal Mak, 'Rights and Remedies - Article 47 EUCFR and Effective Judicial Protection in European Private Law Matters' in Micklitz (ed.), n. 19, 236 and Verica Trstenjak, 'General Report' in Verica Trstenjak and Petra Weingerl (eds), The Influence of Human Rights and Basic Rights in Private Law (Springer 2016) 3 .

25 See Simon Whittaker, 'Who Determines What Civil Courts Decide? Private Rights, Public Policy an EU Law' in Leczykiewicz and Weatherill, n. 1, 89.

26 Micklitz, n. 19 and on the shifts in consumer law in particular, Hans-Wolfgang Micklitz, 'The Consumer: Marketised, Fragmentised, Constitutionalised' in Leczykiewicz and Weatherill, n. 8, 21. See also, Trstenjak and Weingerl (eds), n. 26.

27 See Case C-119/15 Biuro EU:C:2016:987, discussed further below. 
and the right to a defence are transforming the role of the collective action at the national level and thus the relationship between individual and collective redress. ${ }^{28}$

Notwithstanding this evolving space for judicial cooperation and dialogue, little research has been undertaken either on the mechanisms and techniques of cooperation and dialogue, or on the impact of CJEU jurisprudence in the legal system of the referring court and across other systems. ${ }^{29}$ The increase in the number of preliminary references is one of a number of trends underpinning the contributions to the text. It coincides with other developments that shape EPL and European integration and which call for an investigation into the existence and character of interdependences in the European space. ${ }^{30}$ These include the enlargement of the EU, the shift in the harmonization policy of the Union legislature from minimum to maximum to targeted maximum harmonization and the expanding role of regulatory bodies in the enforcement of EU law. It is submitted that the role and influence of courts and the increasing relevance of national regulators in the monitoring and enforcement of consumer law necessitates ${ }^{31}$ a reconsideration of the dynamics of institutional dialogue or trialogues between domestic and European actors, and particularly

28 See Case C-312/14 Banif Plus Bank EU:C:2015:794 and Case C-381/14 Sales Sinués EU:C:2016:252.

29 Which might depend on the relevant area of private law and the way in which this is regulated for in the national legal systems, for example, whether there is a civil or a consumer code, or whether Union legislation (generally, directives) are transposed via individual pieces of national legislation.

30 On the one hand, we can consider the interdependence between EU law and national private law and how best to understand the interdependence between the two in private law relationships; see Carla Sieburgh, 'A Method to Substantively Guide the Involvement of EU Law in Private Law Matters' (2013) ERPL 1165, who advocates a particular role should being attributed to fundamental rights and especially the CFR in understanding these interactions. On the other, we can analyse this interdependence in light of the spillover effects that emerge from the interactions and transformations that derive - at least initially - from the launching of the preliminary reference procedure and the relationship that is (re)established between the national court and the CJEU, and which affect not only courts in the referring and other Member States but the national legislative bodies and administrative enforcement agencies.

31 This issue is even more important given the reform of Regulation 2006/2004 on Cooperation between National Authorities Responsible for the Enforcement of Consumer Protection Laws. A proposal for a new regulation was published in May 2016. See European Commission, 'Proposal for a Regulation on Cooperation between National Authorities Responsible for the Enforcement of Consumer Protection Laws' COM(2016) 283 final. 
between judges and regulators exercising relevant advisory functions. ${ }^{32}$ The examination of the processes and actors engaged in enforcement is not without conflict however. ${ }^{33}$ Institutional rents are eroded unevenly given the different choices made by Member States when identifying enforcement bodies, the instruments available to them and their objectives. While judiciaries obtain power over national executives, they also cede some of their newly-acquired powers to independent regulators. ${ }^{34}$

32 Consider for example, the French Commission des clauses abusives, established by L. 822-4 of the Consumer Code, which can examine standard form contracts and recommend the removal or amendment of clauses which are unfair, i.e., which essentially create an imbalance against the non-professional or consumer. The Commission can also hear references from a judge for a determination on whether a contract term is unfair. Its recommendations and opinions are published online at http://www.clauses-abusives.fr/ (Last accessed: 25.10.2016). A similar body exists in Belgium (see http://economie.fgov.be/fr/spf/structure/ Commissions_Conseils/Commission_clauses_abu/avis/\#.WBBeeEYuNkU (Last accessed: 26.10.2016). In the Netherlands, standard contract terms are drafted per sector by trade associations, having been determined ex ante to be fair. In the UK, the Competition and Markets Authority, which replaced the Office of Fair Trading in 2014, is responsible for assessing mergers, markets and the regulated industries, with competence to enforce competition and consumer law. It does not assist consumers directly but has a role to play educating businesses on compliance; it aims to promote competitive markets, and compliance with consumer protection law via the provision and dissemination of information, advice and education, dialogue, warning, undertakings, penalties and then through civil and criminal actions. It can apply - per Part 8 of the Enterprise Act 2002 - to the courts for an enforcement order in light of a violation of consumer law, and following the Consumer Rights Act 2015, can impose enhanced consumer measures on businesses (which can include training, monitoring of compliance, and voluntary redress schemes). Other bodies also have a role to play in regulating unfair terms, either via an injunction (to prevent a business from using, proposing to use or recommending the use of a term that appears to be unfair) or via an enforcement order (which may also provide redress to consumers who have suffered loss (including monetary compensation)); these include the Chartered Trading Standards Institute, the Trading Standards Services, and others, under the Unfair Terms in Consumer Contract Regulations 1999.

33 See Richard A. Posner, 'Regulation (Agencies) versus Litigation (Courts): An Analytical Framework' in Daniel P. Kessler (ed.), Regulation vs. Litigation: Perspectives from Economics and Law (University of Chicago Press 2010) 11, who examines the relationship between common law judging and administrative regulation as mechanisms of social control, identifying the methods used in each and the overlap between the two. In relation to consumer enforcement see Fabrizio Cafaggi, 'The Great Transformation: Administrative and Judicial Enforcement in Consumer Protection: A Remedial Perspective' (2009) 21 Loyola Consumer Law Review 496.

34 See Cafaggi and Muir Watt, n. 22. 


\section{(ii) Instruments and Objectives of Judicial Dialogue}

This introduction aims specifically to ascertain and map existing and emerging patterns, mechanisms and techniques of institutional dialogue and cooperation, which are further examined in each of the contributions with a focus on the relevant area of EPL. In terms of its character and aims, judicial dialogue and, moreover, 'judicial cooperation in civil and commercial matters', is multi-faceted. These strands of interaction might be vertical, for example arising between the national and European courts, ${ }^{35}$ or horizontal, between the national courts, on the one hand, and between the CJEU and the ECHR, ${ }^{36}$ on the other. Dialogue might occur between courts and legislatures, or courts and regulators, giving rise to trialogues or even tetralogues. ${ }^{37}$ It can be understood to have varied objectives, which may diverge depending on the perspective adopted, that is, of the national or European courts, of legislatures, academics, civil society bodies or individuals.

Dialogue may aim promote communication or 'conversation' not only concerning the content of European private law norms, that is, their

35 Typically that which emerges via the preliminary reference procedure. See Tridimas, n. 23, 403.

36 Which arises when cross-references are made between the two courts.

37 Consider the facts in a recent case, which brings to the fore the significance of the EU's experimentalist governance approach, in this context, in the telecoms sector: Case C-28/15 Koninklijke KPN and Others EU:C:2016:692. The national regulatory authority had previously issued a decision implementing a recommendation of the European Commission that was subsequently overturned by the national court on judicial review; the court's decision required the authority to depart from the recommendation. In light of a consultation procedure established under the relevant directive, the national authority notified the Commission, which initiated an investigation considering that the judicial decision constituted a barrier to the functioning of the market. The case referred arose from a subsequent decision given by the national authority, again implementing the Commission's recommendation; the national court requested clarification on its discretion to provide for a decision against the national regulatory authority and the Commission's recommendation on the basis of national legal and factual concerns (namely, the nature of the Dutch market). Both the A-G and Court held that the national court could depart from the Commission's recommendation (but that this should be done in limited circumstances) and 'only where it considers that this is required on grounds related to the facts of the individual case, in particular the specific characteristics of the market of the Member State in question'. As such, the national court can overturn the decision of the regulatory authority, thus giving it the role of a de facto regulator (see the comments of Marta Cantero on the AG's Opinion: http://eulawanalysis.blogspot.lu/2016/05/testing-eu-experimentalist-gov ernance.html. Last Accessed: 22.10.2016). 
interpretation, but also in relation to the factors that shape their application (in particular, procedural rules). Indeed, the use of the preliminary reference procedure, and the dialogue to which it gives rise, has been a powerful instrument of legal change in EPL and has emerged as a driver of innovation of both substantive and procedural rules as engaged and utilized at the national level. To take an example: the national courts have long been empowered to police market practices using preventative and repressive measures to deter and stop unfair behaviour; however, the role of the national judge applying national law which transposes EU law may differ from that of the national judge who applies purely domestic law. ${ }^{38}$ Whether the effects of judicial dialogue in this realm - for example, the obligation established by the CJEU which requires national courts to examine unfairness of contract terms ex officio - will transcend those areas of law directly affected by the preliminary reference (therefore leading to the expansion of the approach or interpretation identified to other areas of private law), or indeed, other areas made up of mandatory rules, remains to be seen. It seems that such steps are taking place, at least in the area of consumer law itself. ${ }^{39}$

Dialogue in European private law might be conceived as an empowerment tool ${ }^{40}$ in three ways:

38 Consider, for example, in Spain, where the judge is generally understood to have a passive role in relation to the parties to the (possibly) consumer protectionrelated case on the basis of the principle of disposition; on the basis of the CJEU's jurisprudence (largely but not exclusively), as discussed immediately below, relating to unfair contract terms, it is difficult for the judge to identify what his or her role should be, how far he or she should go in determining if the contract is a consumer one, the sufficiency of the evidence and legal arguments advanced and so forth. These considerations are also shaped by rules of national civil procedure, in which the European Commission has recently taken a significant interest. The Max Planck Institute in Luxembourg will submit a study (JUST/2014/RCON/PR/ CIVI/0082) to the European Commission on the impact of national civil procedure on the enforcement of EU consumer rights (and on the operation of the principle of mutual trust) in December 2016.

39 For example, the ex officio control requirements on the national courts no longer apply only in respect of the Unfair Contract Terms Directive 1993/13/EC but have been extended to consumer sales and consumer credit in Case C-497/13 Faber EU:C:2015:357 and Case C-377/14 Radlinger EU:C:2016:283, respectively. The spillover of these references into the national legal systems is not clear, however, as procedural rules still tend only to provide for an obligation for ex officio control in relation to unfair contract terms; even where a power might be developed along these lines in other areas of consumer law, it seems that judges remain reluctant to engage with it.

40 The literature on the role of courts in European law making has been led by Joseph H.H. Weiler, 'The Transformation of Europe' (1991) 100 Yale L.J. 2403 
(1) It might help national courts and the CJEU to manage commonalities and divergences - whether micro or macro - that emerge from the implementation of Union law in national private law systems and which shape its enforcement. On the face of it, the Union legislature or the CJEU is best placed to identify the existence of divergences or commonalities in national legal cultures, whether substantive (concerning the transposition of norms) or procedural (concerning rules and cultures of national civil procedure). Conflicts arise in a multilevel system where competences are divided and shared; they exist, for example, between interpretations rendered at the Union and national levels, and are generated inter alia within the national system or via spillovers from the descent of the preliminary ruling and the application of the CJEU's interpretations within the diverse national traditions of the Member States. ${ }^{41}$ Dialogue might facilitate

and Karen J. Alter, Establishing the Supremacy of European Law: The Making of an International Rule of Law in Europe (OUP 2001).

41 In this respect, it has been advanced that dialogue reflects neofunctionalist and particularly, revised legal-orientated - understandings of integration, theories developed by Haas in the 1950s, and subsequently, by Alec Stone Sweet and others in the 1990s; Ernst Haas, The Uniting of Europe (Stanford University Press 1958) 16. It was considered that the construction of greater economic interdependence among states, as well as increased social and political interdependence (in respect of the free movement of goods, services, capital and labour) would generate further integration through 'spillover' effects, both political and functional in their nature (Leon Lindberg, The Political Dynamics of European Economic Integration (Stanford University Press 1963) 10). Reconceptualizations of neofunctionalism in the 1980s and 1990s highlighted the legal dimension of integration, with key European legal principles 'penetrating' or 'overlaying' national norms, shaping the interrelation between the national and EU legal orders; Anne-Marie Burley and Walter Mattli, 'Europe Before the Court: A Political Theory of Legal Integration' (1993) 47 International Organizations 41, 43 and Alec Stone Sweet and Wayne Sandholtz, 'European Integration and Supranational Governance' (1997) 4 Journal of Public Policy 297. Subsequently, the 'integration through law' school highlighted, in the context of the existing neofunctionalist, intergovernmentalist and supranationalist scholarship, the 'dual character of supranationalism', namely, the intertwinement of legal and political processes (Joseph H.H. Weiler, 'The Community System: The Dual Character of Supranationalism' (1981) Y. Eur. Law 267); law is understood as 'both the object and agent of integration' (that is, integration of law, and integration through law, respectively (Mauro Cappelletti, Monica Seccombe and Joseph H.H. Weiler (eds.), Integration Through Law: Europe and the American Federal Experience (de Gruyer 1985) 42). Further still, it has been suggested that the balance between cooperation and hierarchy inherent in the relationship between the national courts and the CJEU rather suggests that judicial dialogue reflects an understanding of cooperative supranationalism, and 'interaction, dialogue and compromise' (Anthony Arnull, 'Judicial 
the scope for national courts (as well as the CJEU) to resolve, or at least manage, conflict. Based on the principle of effectiveness, judicial dialogue has provided national courts with new procedural instruments. Dialogue might therefore be conceived as a tool that empowers national courts against the national legislature; that is to say, it might facilitate the role of the national court, instead of, or at least complementary to, the legislature, in generating coherence and filling the gaps in a potentially fragmented - internally to a Member State and across the Member States - body of implementing legislation. ${ }^{42}$

(2) Dialogue might contribute to the better monitoring and enforcement of EU consumer law. It might consist of and include inter alia, the possible scope for national courts to police terms and practices beyond the specific indications given by the parties, ${ }^{43}$ for example, in relation to the ex officio control of consumer contract terms. ${ }^{44}$ It might also encompass the possibility for the national court to expand the effects of injunctions beyond the spheres of the litigants to the specific dispute, and furthermore, the extraction and application of general principles by various courts to areas which do not fall within the immediate scope of EU primary law or secondary law but which nevertheless come to form part of EU law. Such an impact is identifiable in the development of state liability, for example. ${ }^{45}$

(3) Dialogue might enable national courts and regulators to address social problems arising within national and European contexts. This might encompass, for example, issues that have become increasingly evident post-economic crisis; these concerns have included

Dialogue in the European Union' in Julie Dickson and Pavlos Eleftheriadis (eds.), The Philosophical Foundations of European Union Law (OUP 2012) $109,119)$.

42 See Cafaggi, n. 22, 289.

43 While it might also empower private individuals in domestic and crossborder contexts, as in Case C-171/11 Fra.Bo EU:C:2012:453.

44 Including inter alia Case C-240/98 Océano [2000] ECR I-4941, and the cases that followed, including, inter alia: Case C-227/08 Martin Martin EU:C:2009:792; Case C-137/08 VB Pénzügyi Lízing EU:C:2010:659; Case C-243/08 Pannon GSM EU:C:2009:350; Case C-453/10 Pereničová and Perenič EU:C:2012:144; Case C-618/10 Banco Español de Crédito EU:C:2012:349; Case C-470/12 Pohotovost' EU:C:2014:101; Cases C-482, 484, 485 and 487/13 Unicaja Banco and Caixabank EU:C:2015:21; Case C-497/13 Faber EU:C:2015:357; Case C-32/14 ERTSE EU:C:2015:637; and Case C-169/14 Sánchez Morcillo EU:C:2014:2099.

45 C-6/90 Francovich [1991] ECR I-5357, C-46/93 Brasserie du Pêcheur [1996] ECR I-1029 and C-224/01 Köbler [2003] ECR I-10239, among others. 
many issues relating to consumer protection, such as consumer credit, housing (and the credit that accompanies it), and investor protection. ${ }^{46}$

Thus, institutional dialogue may be strategic; it may aim to change directly or indirectly, intentionally or unintentionally, national norms via legislation or case law. It may also operate as a vehicle of cross-referencing and cross-fertilization, as a means of exchange of knowledge, ideas and opinions, as a mechanism of compromise or as a tool of deliberation, in order to promote a specific outcome through collaboration. Indeed, in this light the book purports to facilitate learning and the exchange of knowledge and ideas between national and European judges and academics. National systems of private law diverge in respect of their engagement with particular implementation techniques, the determination of which will have further consequences in respect of the scope for spillover effects. Divergences in national systems will be relevant in terms of the determination of including EU legislation into civil codes or general statutes, or alternatively, the enacting of a single statute and thus the limitation of spillover effects. ${ }^{47}$ In some Member States, consumer law exists as a separate and even insulated body of rules; in others it is integrated into civil codes. It might form part of private law with its own specificities concerning the number and intensity of mandatory provisions, the function of default rules, and the power of the judges to raise questions of their own motion. ${ }^{48}$ It has been shown that the use of consumer codes in contrast to the transposition of Union legislation into individual statutes, or the integration of

46 National courts have often complemented the tasks of regulators in monitoring renegotiations of loans and restructuring of personal debts and bankruptcy. See the contribution of Gomez and Lyczkowska herein.

47 See Angus Johnston, 'Spillovers' from EU Law into National Law: (Un) intended Consequences for Private Law Relationships' in Leczykiewicz and Weatherill, n. 1, 357.

48 This often also shapes the approach adopted by the national judge. For example, in terms of the role of the judge in Portugal, the judge will often apply general contract law as opposed to specific consumer law due to his or her lack of familiarity with the latter; see Catarina Frade and Mariana Pinheiro Almeida, 'Country Report Portugal' in Hans-W. Micklitz and Irina Domurath (eds), Consumer Debt and Social Exclusion in Europe (Ashgate 2015) 47, 60. The same situation also arises in Spain, where it is unclear whether the national judge should apply consumer legislation when the consumer's lawyer only invokes general provisions of the civil code or of contract law, and not specific consumer law legislation (see Max Planck Institute Study on National Civil Procedure, JUST/2014/ RCON/PR/CIVI/0082, Fernando Gascón Inchausti, 'National Report of Spain'; forthcoming). 
consumer law into a civil code, generates different consequences in terms of the relationship between private and consumer law. If each is conceived to be distinct, for example, the impact of judgments rendered by the CJEU via the preliminary reference procedure may be rather limited to the area of consumer law. That is to say, such a judgment is unlikely to have a broader impact across other areas of private law or across the systems of the Member States other than that of the referring court.

\section{(iii) How do CJEU Judgments Promote or Reduce the Space for Institutional Interactions?}

As this book aims to examine the role played by dialogue as a mechanism in adjudication in multilevel systems, the added value in looking beyond courts themselves towards the dialogue that exists between courts and legislatures, as well as regulatory and administrative authorities, will also be analysed. The choice and reach of the Union's legislative instrument constitutes only the initial step in EPL development; the effects of these determinations on the integration of EU law into national systems and of national legal systems into European law can only be evaluated by examining how it is applied and enforced at the national level (not only by courts but also by administrative and regulatory authorities). This necessitates an analysis of the dialogue that arises from the national courts and the CJEU, and the nature of the judgment given by the latter. ${ }^{49}$ Much of the scholarship to date on the impact of EU primary and secondary legislation has not fully accounted for the role that the character of the judgment rendered by the CJEU might play in respect of the implementation, impact and evolution of Union law within the different national traditions and on the scope for dialogue between the Luxembourg Court and the national judge. ${ }^{50}$ By making reference to the character of the CJEU's judgment, we can engage, for example, the distinction made by Tridimas between the specificity of the ruling rendered by the CJEU. ${ }^{51}$ According to Tridimas'

49 Previous attempts to uncover dialogue in the EU space have largely been confined to the sphere of constitutional dialogue; consequently, it has received relatively little explicit consideration in private law. Thus, while the text aims to build on the existing literature concerning judicial dialogue, it extends beyond this focus in order to engage substantive development areas directly concerning private law development in which key examples of judicial dialogue can be identified, thus allowing for the transcending of the boundaries between the public and private.

50 See however Arthur S. Hartkamp, European Law and National Private Law (Intersentia 2nd edn., 2016). More broadly Weiler, n. 44.

51 Tridimas, n. 23, 403, 409-10. 
taxonomy, three types of rulings might be rendered by the CJEU: (1) one which is so specific that the national court has no discretion to exercise ('outcome cases'); (2) one which provides the national court with guidance as to the resolution of the dispute ('guidance cases'); and (3) one which is so general as to rather defer to the national court ('deference cases'). ${ }^{52}$ We can speculate as to how the nature of a ruling might not only impact the final decision of the referring court, in respect of which the preliminary ruling initially arose, but how it might also impact the nature of the subsequent decisions of the courts of the Member States and the nature of integration that emerges therefrom. ${ }^{53}$ This impact might be reflective of a technique based on conform interpretation, might encompass disapplication of national rules, ${ }^{54}$ might amount to the making of a (further or indeed separate) preliminary reference, ${ }^{55}$ might result in the engagement of comparative analysis, or indeed, might generate a combination of these possible outcomes. ${ }^{56}$ While these lines of enquiry rather extend beyond the scope of this text, we can posit that an approach to rendering a judgment based on conform or consistent interpretation might lead to a softer form of integration; an approach based on the disapplication of national rules suggests a stronger form, which might only be engaged if the national judge cannot identify a satisfactory solution via conform

52 This is explored, for example, in relation to the evolution of extra-contractual liability, and the scope for state liability, in Timmermans' contribution.

53 Further examples of these 'judicial techniques' can be found and are explained in greater detail in the 'JUDCOOP' Handbook: European University Institute, Centre for Judicial Cooperation, 'European Judicial Cooperation and Fundamental Rights: Some Practical Guidelines' (Available at: http://www.eui. eu/Projects/CentreForJudicialCooperation/Documents/JUDCOOPdeliverables/ JUDCOOPdeliverables/JUDCOOP\%20Guidelines $\% 20-\% 20$ Multilingual $\% 20$ version.pdf; Last Accessed: 16.05.2016).

54 Along the lines of the Simmenthal doctrine, Case C-106/77 Amminstrazione delle Finanze dello Stato v Simmenthal [1978] ECR I-0629. Case C-555/07 Küküdeveci, n. 25, in relation to non-discrimination on the grounds of age.

55 The preliminary reference might be used for different purposes, depending on the court (for example, if a lower-court judge anticipated that his or her interpretation or disapplication of national law might generate a negative reaction from a higher-court judge), and depending on the basis of its engagement.

56 For example, in the case law on the rights of same-sex couples in Spain, the Spanish Constitutional Court adopted a combination of comparative reasoning and consistent interpretation techniques to open up a space for the recognition of same-sex relationships in the national legal systems; see, for example, Constitutional Court, STC 198/2012, 06.11.2012 (Available at: http://hj.tribunalconstitucional.es/ $\mathrm{HJ} / \mathrm{es} /$ Resolucion/Show/23106; Last Accessed: 21.06.2016), particularly significant in an area in which the existence of consensus across Europe is contentious. 
interpretation. ${ }^{57}$ Furthermore, the effect of the reference for a preliminary ruling might depend on the nature of the ruling rendered, which can be tied to the taxonomy advanced by Tridimas, namely, whether it is prescriptive (either detailed in advancing a particular solution or simply setting out a principle), promotional or deferential.

Judicial dialogue can also facilitate our understanding of how the level and degree of legal integration is shaped by the boundaries between consistent and inconsistent interpretations of EU law, defining the scope of spillover effects in respect of non-harmonized fields and the margin of discretion left to national institutions when implementing EU law and adapting those areas which have not been harmonized. ${ }^{58}$ It is possible to elaborate upon how the interplay between the vertical and horizontal dialogue brings about new forms of development of European private law. The CJEU might be 'indirectly' pushed via the national courts to coordinate implementation processes that influence the role of the latter in monitoring and policing forms of market regulation through private law instruments. These would include mechanisms like fairness in contractual terms and deceptive and aggressive selling practices. More dramatic changes are likely to become evident as the interaction of the case law on freedoms and distinct areas of private law is examined in more depth. ${ }^{59}$

57 Per, for example, the approach seemingly advocated by the CJEU in Case C-282/10 Dominguez EU:C:2012:33.

58 This concerns, as noted above, the principle of procedural autonomy. National civil procedure has largely been deemed to be a matter that falls outwith the competence of the Union legislature, that is to say, which is not caught by the 'usual' internal market legal basis of Art.114 TFEU. Thus, with the exception of cross-border civil procedure, relating to issues of private international law, procedure is generally a matter for the Member States. The Union legislature has only made limited inroads into national procedure, with the Directives on Injunctions for the Protection of Consumers' Interest (Directive 2009/22/EC) and on Alternative Dispute Resolution for Consumer Disputes (Directive 2013/11/ EU), the Regulation on Consumer Online Dispute Resolution (Regulation 524/2013/EU) and the Recommendations on Collective Redress (Commission Recommendation on Common Principles for Injunctive and Compensatory Collective Redress Mechanisms in the Member States Concerning Violations of Rights Granted Under Union Law of 11.06.2013).

59 See Arthur S. Hartkamp, 'The Effect of the EC Treaty in Private Law: On Direct and Indirect Horizontal Effects of Primary Community Law' (2010) 18 ERPL 527; Paul Verbruggen, 'The Impact of Primary EU Law on Private Law Relationships: Horizontal Direct Effect under the Free Movement of Goods and Services' (2014) 22 ERPL 201; Emanuela Navarretta, 'Libertà fondamentali dell'U.E. e rapporti fra privati: il bilanciamento di interessi e i rimedi civilistici' in Francesco Mezzanotte (ed.), Le 'libertà fondamentali' dell'Unione europea ed il diritto privato (Rome Tre-Press 2016) 41. 
for example, the expansion of the principle of the 'direct effect' of the four freedoms is likely to modify the systems of sources of law and the balance between 'private individual' and 'collective' autonomy. ${ }^{60}$

\section{(iv) The Impact of Institutional Dialogue on the Development of European Private Law}

The book adopts a particular methodology, to examine the entire 'cycle' of jurisprudence arising in the substantive areas of the contributions, from the reference of the national court, to the preliminary ruling of the CJEU, to the subsequent decision of the referring court. The chapters also examine the (potentially strategic) interaction that arises between the courts and with other institutions, including the national and European legislatures, regulatory agencies and alternative dispute resolution entities. Moreover, the contributions also begin to unpeel the notion of the 'impact' of the case on the other courts of the referring Member State (and beyond the area of law in which the reference arose, a cross-sectoral impact) and the impact of the case on the case law of other Member States (a cross-border impact). ${ }^{61}$ Certain chapters do this by tracing the relevant cases, from the national court's decision to make a reference to the CJEU, to the reasoning and judgment rendered by the A-G and the Court, and the transfer of the case back to the referring national court.

This approach purports to facilitate the identification of pertinent conflicts between national and Union law, as they emerge in the national systems, and the putative tension that might arise as the case is referred back to the deciding court, for example, when the preliminary reference was motivated by conflicting interpretations of EU law. By use of this methodology, the scope for interaction (cooperative or conflicting), the use and mechanisms of dialogue and cooperation, and the subsequent impact, can be uncovered.

The component parts of this rough analytical framework of judicial dialogue are deepened in the contributions to the text, through substantive case studies cutting across areas of EPL. Relevant areas of substantive

60 See Stephanie Law, 'The CJEU as a "Laboratory" of Comparative Analysis: A Theoretical and Case-Based Study of the Europeanisation of Private Law', EUI Ph.D. Thesis, 2014.

${ }_{61}$ This approach has been adopted in drafting the JUDCOOP handbook and is currently used in the ACTIONES and REJUS projects, led by Fabrizio Cafaggi and funded by the European Commission's Directorate-General for Justice and Consumers. This cycle can be identified in the cases stemming from Aziz to Sanchez Morcillo, for example. 
law include: state liability, and the impact of CJEU jurisprudence and dialogue in the development of state liability at national level; consumer contract law, its contribution to the development of general contract law and market regulation via contract; and fundamental rights. These areas diverge in respect of the sources of their norms (consumer contract: legislation; fundamental rights: national constitutions/primary legislation/ general principles; state liability: CJEU case law), and the extent to which the nature of their development coincides with judicial dialogue. As noted above, where relevant, the chapters aim to track the relevant cases along different courses. Each chapter identifies: different types of conflict (i.e., between national and EU law and between EU law norms, including between fundamental freedoms and fundamental rights), the making of the preliminary reference by the national court and the factors shaping the decision to refer, the significance of judicial cooperation in the CJEU's rendering of its interpretation, the impact of the preliminary reference on the referring state, and the cross-border impact on other national legal orders. The chapters use this tracking mechanism as a means to identify the nature and the objectives of the dialogue arising therein. This might be vertical or horizontal; the chapters examine firstly the ascent of the case to the Luxembourg Court (and the rationales underpinning the reference; this might include empowerment, the scope for which diverges between sectors) and thereafter, its descent from the CJEU. The preliminary reference procedure establishes a direct vertical dialogue between the national courts and CJEU, and necessarily cuts across vertical and horizontal interactions at the national and European levels. With a contribution from Scirica, the book also offers a perspective that extends beyond the largely European focus that arises from the other chapters. This allows for a transatlantic analysis of the various techniques of judicial interaction, ${ }^{62}$ to promote dialogue and resolve conflicts arising between the national courts and the CJEU, on the one hand, and the federal courts and the US Supreme Court, on the other. The EU and the US, two of the world's largest economies, are politically, economically and culturally intertwined at various levels. ${ }^{63}$ There exists a considerable body of scholarship on

62 Including, within the US system: (1) consistent interpretation; (2) preliminary reference; (3) proportionality; (4) comparative reasoning; (5) mutual recognition; (6) disapplication; and (7) deferential techniques; see the contribution of Scirica to this text.

63 Following the Marshall Plan of 1948 (the Foreign Assistance Act 1948), the US first sent observers to the then-ECSC in 1953; diplomatic relations that evolved via the establishments of missions and delegations were formalised in 1990 with the adoption of the Transatlantic Declaration and advanced further by the New 
diplomatic relations, security and defence, and of course, on trade between the EU and US as well as on those matters falling within the area of Justice and Home Affairs. ${ }^{64}$ However, there has been little research undertaken on the scope for transatlantic judicial and institutional dialogue. ${ }^{65}$ This book therefore facilitates a first step and aims to highlight the key paths of future research. The existence of cooperation and dialogue that are examined predominantly in the EU context - with a focus on the horizontal and vertical relationships between the national legal systems of the Member States and the EU, as well as the ECHR regime - could be extended in the abstract to EU-US cooperation, particularly in areas where it is necessary to develop mechanisms for managing the plurality of regulatory regimes. ${ }^{66}$ From the perspective of EPL, the scope for cooperation and dialogue becomes increasingly pertinent to the issue of effective consumer enforcement and its related fields. ${ }^{67}$

The book also examines the significance of national traditions and cultures, and particularly, the manner in which national peculiarities influence the foundations of dialogue, that is, predominantly the determination

Transatlantic Agenda, adopted in 1995. The Transatlantic Economic Partnership was subsequently entered into, covering bilateral and multilateral trade and which has led to the development of mechanisms to avoid obstacles to trade and the liberalization of trade within the WTO context. The Transatlantic Economic Council was established in 2007 and six years later, US-EU High Level Working Group on Jobs and Growth advised that the EU and US begin to negotiate an agreement on trade and investment (what continues to be negotiated as the Transatlantic Trade and Investment Partnership).

64 European Parliamentary Research Service, 'EU-US cooperation in Justice and Home Affairs - An Overview' PE 580.892 (Brussels 2016).

65 Certain frameworks for dialogue have been advanced; these include, for example, the Trans-Atlantic Business Council, the Trans-Atlantic Consumer Dialogue and Trans-Atlantic Policy Network, all of which seem to be fundamentally pro-trade. Moreover, there have been studies - mostly political science, albeit with a key legal dimension - into the existence and character of transatlantic cooperation in various areas; see for example, Mark A. Pollack and Gregory C. Shaffer (eds), Transatlantic Governance in the Global Economy (Rowman \& Littlefield 2001) and Mark A. Pollack, The Political Economy of the Transatlantic Partnership (RSCAS, European University Institute 2003).

66 See Paul Schiff Berman, Global Legal Pluralism (CUP 2012) 152 et seq.

67 Which includes, of course, the CJEU's finding of invalidity of the old Safe Harbour agreement in Case C-362/14 Schrems EU:C:2015:650 (which highlighted the need for clarifications from the US institutions in this context), the significance of the Safe Harbour Framework and the new EU-US Privacy Shield agreement, and which brings to the fore not only judicial cooperation but cooperation between regulatory and enforcement bodies (in the context of data protection between the European Data Protection Authorities and the Federal Trade Commission). 
of the national court to make a preliminary reference to the CJEU, and consequences of dialogue, comparing the diverse, local institutional frameworks, which provide indications as to the openness or resilience of the Member States to the Europeanization of private law. The contributions aim to transcend the discussion of 'if dialogue takes place' and engage at a more fundamental level with its foundations, character and impact, looking to identify and evaluate the consequences of its different forms, that is, whether it might generate empowerment strategies with the purpose of providing the courts - national and European - with tools to facilitate and promote to compliance with Union legislation and CJEU jurisprudence, or to encourage directly or indirectly spillover effects in areas falling outside the Union's direct field of competence. ${ }^{68}$

\section{(v) Actors and Dynamics of Institutional Dialogue in Private Law Enforcement in Light of the Charter of Fundamental Rights}

As submitted above, institutional dialogue is stimulated by the application of the principles of equivalence and effectiveness in the context of the enforcement of EPL, and particularly consumer law rules; it is further advanced by the related notion of effective judicial protection, reflected in Art.47 CFR. The relationship between the actors engaged in the enforcement of EPL, whether courts or regulatory bodies, and Art.47 CFR, is a matter that continues to lack clarity.

An interesting issue concerning this relationship has recently been decided by the CJEU, in which the Polish Court of Appeal engaged the CJEU's decision in Invitel in its preliminary reference. ${ }^{69}$ The case concerned whether a judicial ruling, in which contract terms are found to be unfair, can have subsequent binding force in respect of traders who are not party to the judicial proceedings in which the term is found to violate consumer law, but who use the same terms and conditions. ${ }^{70}$ Polish law has recently been reformed $;^{71}$ while it is no longer the case,

68 See Johnston, n. 51, 357.

69 See Biuro, n. 30. The authors would like to extend particular thanks to Mateusz Grochowski for his assistance in better understanding the case and its background and who has also prepared the case note on the national judgment for the REJUS handbook

70 See also Hans-Wolfgang Micklitz, 'A Common Approach to the Enforcement of Unfair Commercial Practices and Unfair Contract Terms' in Willem van Boom et al (eds), The European Unfair Commercial Practices Directive: Impact, Enforcement Strategies and National Legal Systems (Ashgate 2014) 173.

71 Act Amending the Act on Competition and Consumer Protection, which came into force in April 2016. The previous situation was governed by Arts. 
such judgments previously had erga omnes effect. That is to say, while individual control could be made on the basis of Art.385(1) of the Civil Code, abstract control could also be made by the judiciary. Moreover, the Court of Competition and Consumer Protection, a specialized court in Warsaw, also had jurisdiction to hear actions brought by all parties who had concluded a contract including such terms with a trader. If found to be unfair, the relevant terms were published in a register of unfair terms in line with Art.479(43) of the Code of Civil Procedure; this process of publication allowed for administrative control as the President of the Court of Competition and Consumer Protection was able to determine, by comparison, if contract terms challenged were the same or similar to those included in the register. It is worth noting that this body is an administrative one and is not specialized in the interpretation and application of contract law. The President could then impose an administrative fine on the trader for his violation of the unfair terms law. The practical result was that the judicial finding of unfairness affected not only the parties to the case but all traders using the same or similar terms. The reform repealed the provisions that regulated the 'in abstracto' review of contract terms, and shifted this procedure from the civil courts to the Office of the Protection of Competition and Consumers (represented by its President) with the aim of introducing a unified model of 'in abstracto' control; fines can still be imposed and the parties can appeal to the court itself to challenge the finding. Moreover, the courts can still undertake a review of contract terms 'in concreto', that is, in the context of the relevant contract challenged before it. The decision of the President of the Office will generally bind civil courts.

The reference to the CJEU - which is now largely historical in light of the Polish reform - was made by the Court of Appeal of Warsaw, hearing an appeal from a trader whose contract included unfair terms published in the register. The A-G's Opinion is particularly interesting as he reformulates part of the reference in order to attribute to it an Art.47 CFR dimension concerning the trader's right to be heard. ${ }^{72}$ The A-G's

479[36]-479[45] of the Code of Civil Procedure of 17.11.1964. The new rules are introduced in Arts.23a-23d of the Act on Protection of Competition and Consumers of 16.02.2007.

${ }_{72}$ When the court holds a clause to be unfair, third parties cannot intervene either in the judicial or administrative proceedings; according to the A-G, this should preclude the erga omnes effect of the judgment because otherwise, the right to be heard, warranted to both consumers and traders by Art.47 CFR, would be violated. 
Opinion challenged the system that previously operated in Poland ${ }^{73}$ and called into question the legitimacy of the establishment of a "judicial" black list of unfair terms; rather, he considered this should be a matter for the legislature. ${ }^{74}$ Moreover, he held that Art. 3 UCTD provides the trader with the right to show that the standard term has been individually negotiated by the parties to the contract; in the absence of such a possibility, the A-G held that the trader's right to be heard in Art.47 CFR would also be undermined. ${ }^{75}$ Furthermore, the A-G rejected the notion the Polish system could be said to be the same as that of concern in Invite $^{76}$ because in the latter situation the effect of the judgment applied only in favour of and not to the disadvantage of third parties. ${ }^{77}$ The judgment of the Court deviates fundamentally from the Opinion of the A-G. While acknowledging the Art.47 CFR dimension of the case, and highlighting that effective judicial remedies must be available to traders facing sanctions, ${ }^{78}$ the Court found that the Polish (pre-reform) system was not precluded by the directive. As such, it held that the use of standard contract terms with content identical to that of terms previously declared unlawful by a court, and which have been listed in a national register of unfair standard terms, could be said to be unlawful also with regard to a trader who was not a party to the initial judicial proceedings. Essentially, the Court accepted the establishment of such registers by the courts. Contrary to the A-G, the Court, while it did not examine the erga omnes effects of those findings in detail, developed its own judgment in Invitel and provided that a court's identification of an unfair term may also bind other traders as to their future contracting. ${ }^{79}$ The case shows the deep changes that a reference to Art.47 may generate in respect of the relationships between 'in abstracto'

73 As noted above, the Polish system has been reformed between the time of the submission and the time of decision but the Court has nevertheless decided that it will issue a judgment.

74 Biuro, n. 30, paras. 54-57.

75 Ibid., paras. 64-70.

76 Case C-472/10 Invitel EU:C:2012:242.

77 That is, the same seller, supplier and trader but a different consumer; Biuro. n. 69 , paras. $80-83$.

78 Biuro, n. 30, paras. 26-27 and 43-45. Essentially, providing for review of the question of whether, in light of the relevant circumstances of the case, the terms are 'materially identical', especially in respect of the harmful effect caused to consumers and review of the proportionality of the amount of the fine established.

79 The scope for the extension of the erga omnes effects of judicial decisions in which standard contract terms have been found to be unfair has been advanced by the authors in Fabrizio Cafaggi and Stephanie Law, 'Effect of Collective Proceedings' in Evelyn Terryn et al (eds), Landmark Cases of EU Consumer Law: In Honour of Jules Stuyck (Intersentia 2013) 653. 
and 'in concreto' review of unfair terms and, more broadly, between individual and collective redress. Moreover, it illustrates the impact of dialogue between the national courts, administrative bodies and the CJEU in expanding the erga omnes effect of injunctive relief with regard to both consumers (as in the Invitel case) and traders (per the Court's judgment in Biuro).

From this perspective, numerous questions arise: what are the consequent influences of these trends on the choices made by the EU legislature and initially, of course, by the European Commission: Have the policy choices of the Commission shifted? Do we see a shift from legislation to adjudication? Moreover, do we see a shift from judicial to administrative enforcement, and therein from ex post to ex ante ${ }^{80}$ regulation of consumer law, and EPL generally? From compensatory redress via individual private enforcement towards prevention and deterrence (whether individual or collective, private or public)? ${ }^{81}$ How do the courts continue to shape EPL development? What is the impact on institutional actors

80 Ex ante control is made in France for example by the Commission des clauses abusives and the Commission d'examen des pratiques deloyales commerciales and is established in Part 8 of the English Enterprise Act 2002 and the enforcement procedures of the Competition and Markets Authority.

81 See Franziska Weber and Michael Faure, 'The Interplay between Public and Private Enforcement in European Private Law: Law and Economics Perspective' (2015) 23 ERPL 525, revisiting the conventional law and economics perspective defined by A. Mitchell Polinsky and Steven Shavell, 'An Economic Theory of Public Enforcement of Law (2000) 38 J.Econ.Lit. 45. A decision of significant importance, in which the Court deviates from the Opinion of the A-G, was rendered in December 2016 and will likely have a considerable policy impact and potentially, a deterrent one, across the Member States. In Joined Cases C-154/15, C-307/15 and C-308/15 Gutiérrez Naranjo EU:C:2016:980 paras. 61-62, the Court had to determine whether the temporal effect of a finding of unfairness - in this case with regard to 'cláusulas suelo' or 'floor clauses', which set the 'floor' for minimum interest rates in Spanish mortgage contracts - should be limited. These clauses had been found to be unfair by the Spanish Supreme Court (Judgment No 241/2013 of 9 May 2013), and there was a dispute in the Spanish judiciary as to whether the consequences of the finding of unfairness (namely, the repayment of amounts undue) should be limited temporally and arise only in respect of payments made after the declaration of unfairness. The Court found that the consequences should not be so limited but should rather be retroactive. The result of the Court's judgment is that Spanish consumers can now claim from Spanish banks the repayment of amounts paid in excess on the basis of the unfair term, not only from the date of the finding of unfairness but from the beginning of their loan contract. While it is yet to be seen how it will be implemented in the Spanish system, the judgment is expected to generate considerable economic consequences on Spanish banks. 
in EPL development, beyond the courts and the legislatures? Is EPL developing in such a way as to allow for the protection, of e.g., (EU and national) consumer rights in a networked framework ${ }^{92}$ Such issues arise for example in respect of regulators and administrative authorities who are increasingly engaged in a supervisory role across areas of fundamental significance for consumers, including financial regulation and investment protection, general services (energy, telecom and transport, ${ }^{83}$ and so on) and competition law. ${ }^{84}$ These bodies play a role in policing markets and market practices, one that is becoming increasingly significant at the EU level and across the Member States and which has yet unexplored constitutional dimensions reflected in Art.47 CFR.

\section{OVERVIEW OF THE CONTRIBUTIONS}

This book aims to contribute to the existing research agenda on judicial and institutional dialogue and cooperation by bringing together contributions from judges and legal scholars. The 'added value' of this scholarship is reflected in the engagement of the broad participant body, encompassing academics, practitioners, and national and European judges, as well as the scope, in light of the contributions taken together, for the cross-

82 That is, in a framework of experimentalist governance; see Charles F. Sabel and Jonathan Zeitlin (eds), Experimentalist Governance in the EU (OUP 2010) and Charles F. Sabel and Jonathan Zeitlin, 'Experimentalist Governance' in David Levi-Faur (ed.), The Oxford Handbook of Governance (OUP 2012) 169. New forms of governance underpin the critical examinations undertaken throughout the book, concerning the enforcement of EPL norms against the background of the diversity of the Member States and dialogue between the EU and national institutions at play; it highlights the significance of the framework goals identified (particularly, the protection of consumer rights in light of the construction of the internal market), the communication between actors and institutions engaged in the identification of policy solutions (away from central actors like legislatures and courts to administrative agencies and civil society bodies including consumer protection associations), which are confronted with similar problems, learn from distinct, heterogeneous efforts through reporting endeavours, revise those solutions and begin to identify novel ones via these communication efforts.

83 For example, in the area of energy provision amongst others, the EU's third package of energy market legislation aims to develop the role of consumers as market regulators by establishing rules that allow, for example, consumers to choose freely their own energy provider. For further information: <http://ec.europa.eu/ energy/en/topics/markets-and-consumers/consumer-rights-and-protection $>$.

84 See Hans-Wolfgang Micklitz, 'Regulatory Strategies on Services Contracts in EC Law' in Fabrizio Cafaggi and Horatia Muir Watt (eds), The Regulatory Function of European Private Law (Edward Elgar Publishing 2009) 16. 
fertilization of ideas, opinions and information between national and European traditions and cultures. The chapters of the book attempt, in the different ways set out below, to examine the impact of judicial and institutional dialogue on the evolution of EPL, and the existence and consequences of a shift from a focus on the former to a focus on the latter. The notion of impact evaluation implies a metric but also a conceptual framework, which opens up as opposed to closes the debate on the processes by which European and domestic courts contribute to the creation, transformation and identity of EPL development.

The challenges in defining concretely what is meant by judicial (institutional) interaction, judicial (institutional) cooperation and judicial (institutional) dialogue are reflected in the contributions; indeed, each author tends to begin with a conceptualization of the term used for the purpose of their chapter, outlining the scope of the concept engaged, its limits and also the extent to which it extends beyond a focus on courts (see Cafaggi). The contributions deal with issues arising across substantive areas of EPL; these focuses range from state liability (Timmermans), fundamental rights protections for private parties (Colombi Ciacchi; Safjan; Timmermans) and consumer law (Cafaggi; Law; Gómez and Lyczkowska), and particularly, unfair contract terms regulation (Cafaggi; Józon). Moreover, certain contributions offer a comparative analysis, either between EU Member States (Józon on Hungary and Romania), as engaged by the CJEU (Timmermans) or between the EU and the US legal orders (Scirica on techniques of judicial interaction).

Timmermans' contribution 'looks behind' the 'judicial cooperation triggered by a preliminary reference' to the CJEU, particularly in matters concerning state liability and in cases where a conflict arises between the protection of an economic freedom and a fundamental right. He examines the determinations that give rise to the interaction encompassed in the preliminary reference procedure, that is, the motivation of the national courts in referring a question to the CJEU, at the understanding of this interaction on the part of the CJEU, at the nature of its reasoning and preliminary ruling, and on the way in which this affects the final decisions of the national courts. For this reason, he shifts his evaluation away from the usual lens of analysis, that is, the content of the reference, to focus on the way in which it is made and received, the nature and impact of the Court's judgment (particularly, whether it is concrete or less so) and the cooperation that exists - via the reference procedure - between judges sitting in national courts within one Member State and also that which might be characterized as cross-border. For Timmermans, dialogue is necessarily linked with cooperation, openness to which is necessary on the part of the national courts for the operation of the preliminary reference procedure. 
His contribution therefore examines dialogue which might be more informal (for example, meetings of associations of judges or networks of lawyers and academics) or institutionalized (for example, the establishment of national or European networks or databases of case law allowing national judges quick and easy access to jurisprudence from other national courts and from the CJEU).

Gómez and Lyczkowska examine the existence of judicial interaction that between the national courts and the CJEU - with the aim of identifying why the national courts, and particularly the Spanish courts, seek guidance from the CJEU. Fundamentally, this evaluation is made in light of the relatively large number of references made from the Spanish courts that have generated a line of cases leading to landmark rulings in European consumer law. At first glance, they consider that judicial interaction seems to be based on the notion of collaboration, whereby 'Spanish courts should be considered as very collaborative and committed participants in the development of European consumer law through the expansion and refinement of CJEU case law'. However, recognizing that the references made by the Spanish courts do not follow a consistent or coherent approach, and that the number of references has increased considerably in recent years (and generally only in relation to consumer law), Gómez and Lyczkowska turn to consider whether the examination of the engagement of the Spanish courts - and particularly those of first instance - might not be further picked apart. Thus, from a game-theoretical perspective, they offer an explanation for the behaviour of the Spanish courts and their interaction with the Spanish government on the one hand and the CJEU on the other. They reference two different 'channels' of interaction, building on previous scholarship - low-cost (where the national courts refer to CJEU case law) and high-cost (where the national court requests a preliminary reference from the CJEU for 'assistance' to solve social problems) channel, where the cost to the national court as to this interaction is shaped by the preferences of the national courts and the Spanish government in respect of the levels of unfair contract terms protection sought by each.

For Józon, 'judicial cooperation' is 'the dialogue that takes place between the CJEU and the domestic judiciaries on policy and which implicitly affects the methodology of judicial enforcement' (Józon, 1). It arises on the part of the national court when it searches for a solution to a problem of EU law that it cannot solve. Focusing on the jurisprudence before the Romanian and Hungarian courts and concerning the regulation of pre-formulated contract terms, Józon examines the extent to which these courts use or indeed refrain from using, the preliminary reference procedure (more so in Hungary, and less so in Romania), in light of, and 
as a tool of, their domestic judicial policy in the enforcement of consumer law. Moreover, she evaluates why these courts, operating in legal systems with similar legal cultures and traditions, that is, strongly positivistic, react so differently - in terms of their interaction with the CJEU - to the enforcement of the Unfair Contract Terms Directive. She identifies the different purposes for which the preliminary reference procedure might be used at national level, and the factors that frame its use. She concludes that the use of the preliminary reference procedure is reflective of the way in which EU legislation has been transposed at the domestic level by the legislature and the courts; thus, while the Romanian courts have been able to 'successfully integrate the policy-based and case-law-based reasoning of the CJEU into their domestic judicial discourse', the integration of this policy dimension is absent in the Hungarian system, with the result that the CJEU's interpretation 'remain a foreign body'. This approach in Romania has resulted in less of a need for preliminary references, in contrast to the situation in Hungary, with the result that the Hungarian courts have repeatedly requested preliminary rulings from the CJEU.

The chapter by Law aims to explore the significance of judicial cooperation to the Europeanization of private law through the lens of the evolution of a key concept of national and European private law, namely the concept of the consumer. The chapter first places the development of consumer law in a historical context, at the state and EU level. It recognizes at the outset the diversity of national legal traditions and the disparate character of the legislative consumer acquis, and the potential use, prima facie, of dialogue and its values as a mechanism for integration against this background, particularly via the preliminary reference procedure. In light of the potential problems that stem from the limitations of a formalistic and broad conceptualization of the consumer in Union and national legislation, and the aims and objectives underpinning, the chapter proceeds to examine how the notion of consumer has been legislated for by the EU legislature, key examples of its transposition in the Member States, and its interpretation in the national courts and before the CJEU. This perspective allows for an examination of the potentially lower or higher levels of protection afforded, than otherwise anticipated at the EU level, and for a re-examination of the scope for dialogue in light of the objectives of the Union legislature, and the CJEU, and against the background of an increasing focus on balancing the facilitation of the market with social and fundamental rights concerns.

Safjan argues that the nature of the dialogue that arises between courts is tied to the theoretical approach adopted to understand the relationships that exist between national constitutional standards of fundamental rights protection and those found in the Charter of Fundamental Rights 
(Safjan); each potential theoretical conceptualization of this relationship, he asserts, generates 'a different degree of potential risk of collision and tensions between the different courts'. For Safjan, the potential risk for confrontation and scope for coexistence differ depending on how the application of fundamental rights protected in the CFR are applied in relation to national law; moreover, there exists differing potential for dialogue, which he examines in turn. This relationship might be restrictive, wherein it 'limits the application of the Charter to the national provisions which have been adopted specifically for the purposes of the implementation of EU law'; it might be abstract, which 'extends the application of the Charter to each part of the national law' or it might be functional, that is, 'located half way between the restrictive and the abstract approach, constitutes a kind of compromise between these two'. For Safjan, dialogue with the CJEU must be initiated by the national courts, with 'openness and sensitivity' on both sides, that is, so that this initiation does not become a unilateral, 'one-way message' from the domestic system. It provides a means to respond to the need of the courts to find a balance between the plurality of the Member States' constitutional identities and the integrated EU space, being a 'unique instrument in order to achieve consensus in this fragile matter', shaped by the values of the Union in Art.2 TEU.

The contribution of Colombi Ciacchi focuses on the dialogue that exists between the CJEU and the national courts in cases between private persons in which fundamental rights' protection is at issue, and in particular on the notion of judicial governance, understood as the examination and balancing of conflicting rights, interests and policies. Using two key pieces of jurisprudence as case studies, namely Angonese ${ }^{85}$ and Sturgeon, ${ }^{86}$ she identifies and evaluates the nature of the conflicts of rights, interests and policies arising in each case, from six types of conflicts set out in the introduction. She then proceeds to examine the dialogue - identifying a 'harmonious dialogue' from Angonese, that reflects the direct horizontal effect of the balancing of rights and freedoms on private relationships, and a 'hermeneutical dialogue' which 'runs along patterns of conflicts that are remarkably different from the ones in Angonese' in Sturgeon - that arises between the national courts and the CJEU in their assessment of those conflicts. Concluding by drawing comparative conclusions on how this dialogue contributes to judicial governance of European society, Colombi Ciacchi reflects on the two cases and their impact across national legal

\footnotetext{
85 Case C-281/98 Angonese [2000] ECR I-4139.

86 Joined Cases C-402/07 and C-432/07 Sturgeon and Others [2009] ECR I-10923.
} 
systems, highlighting that while a barrage of criticism has been launched at Sturgeon, and while Angonese has been received much more smoothly, both cases reflect the CJEU's exercise of judicial governance and its protection of fundamental interests of private individuals in the face of their potentially being outweighed by the more powerful interests of private corporate actors.

From the perspective of a judge sitting in a US court, Scirica offers a contribution that allows for a comparative analysis of the mechanisms of judicial interaction in the EU and US systems. He identifies 'judicial interaction' as a set of techniques that could be used to construct a framework for the resolution of conflicts in the EU space, that is, 'to be used by European courts and judges to promote coherence and coordination in areas of fundamental rights protection'. He focuses on seven techniques, including: (1) consistent interpretation (Supremacy Clause doctrine); (2) preliminary reference (question certification); (3) proportionality (rational basis, intermediate scrutiny, strict scrutiny); (4) comparative reasoning (other federal circuit courts, supreme courts, treaties and American Law Institute); (5) mutual recognition (full faith and credit, recognition and enforcement of judgments, stare decisis); (6) disapplication (Supremacy Clause doctrine, pre-emption); and (7) deferential techniques (judicial restraint). Scirica thus first identifies the equivalent techniques existing in the EU legal order and in the US federal and state systems, proceeding to situate these techniques against the background of a succinct account of the US legal systems, and of judicial power sharing. The focus of the analysis then shifts to the operation of these techniques to solve conflicts in the US federal and state courts in respect of questions of fundamental rights, with a detailed discussion of three key pieces of Supreme Court jurisprudence.

The contribution of Cafaggi examines the existence, nature and impact of institutional dialogue on the enforcement of consumer law, and as a 'driver of innovation' of consumer law development. He identifies the scope for and character - whether horizontal or vertical - of both administrative and judicial dialogue, and the potential for dialogue to be transformed into trialogues or tetralogues when other institutional bodies, including for example the national legislature, also become engaged. He identifies, evaluates and compares the forms of institutional dialogue that shape judicial and administrative enforcement of consumer law, taking the jurisprudence that has contributed to the development of the ex officio powers of national courts to engage in the control of consumer law as a key example. Noting that the determinations to engage in dialogue are often strategic, these rationales are examined, as is the role played by the Charter of Fundamental Rights and by the principle of effective judicial 
protection, particularly in light of the limitations faced by administrative regulators, and the obstacles sometimes imposed by national procedural law. Concluding with an analysis of the impact of such dialogue - that is, spillovers - across the Member States, the chapter 'recombines' two types of dialogue in consumer protection: vertical judicial dialogue for civil law enforcement and administrative horizontal dialogue within European networks for administrative enforcement. 